\title{
EVALUASI KUALITAS KIMIA KULIT UBI KAYU (Manihot utilissima) YANG DIFERMENTASI MENGGUNAKAN INOKULAN Aspergillus oryzae
}

\author{
Evaluation of Chemical Quality of Fermented Cassava Peel (Manihot \\ utilissima) using Aspergillus oryzae inoculant \\ Marlia Dwita Saputri ${ }^{1}$, Siti Chuzaemi²) \\ 1) Mahasiswa Fakultas Peternakan, Universitas Brawijaya Jalan Veteran, Ketawanggede, Kec. Lowokwaru, Kota \\ Malang, Jawa Timur, Indonesia 65145 \\ ${ }^{2)}$ Dosen, Fakultas Peternakan, Universitas Brawijaya Jalan Veteran, Ketawanggede, Kec. Lowokwaru, Kota \\ Malang, Jawa Timur, Indonesia 65145 \\ Email: marlia.dwita24@gmail.com \\ Diterima Pasca Revisi: 21 Februari 2021 \\ Layak Diterbitkan: 1 Maret 2021
}

\begin{abstract}
ABSTRAK
Penelitian ini dilakukan dengan tujuan untuk mengevaluasi tentang pengaruh tingkat penggunaan Aspergillus oryzae terhadap kualitas kimiawi fermentasi kulit ubi kayu (Manihot utilissima). Aspergillus oryzae dengan kadar pemakaian yang berbeda yaitu 0\%, 1\%, 2\% dan 3\% digunakan untuk fermentasi kulit ubi kayu dengan waktu inkubasi 96 jam. Penelitian ini menggunakan metode percobaan di laboratorium dengan Rancangan Acak Lengkap (RAL) yang terdiri dari 4 perlakuan dan 3 ulangan sehingga total berjumlah 12 unit. Kualitas kimia yang diamati dalam penelitian ini terdiri dari Bahan Kering (BK), Bahan Organik (BO), Serat Kasar (SK), Lemak Kasar (LK), Protein Kasar (PK) dan Bahan Ekstrak Tanpa Nitrogen (BETN). Analisis varian digunakan untuk menganalisis data hasil penelitian lalu dilanjukan dengan uji Uji Jarak Berganda Duncan (UJBD). Hasil penelitian menunjukkan bahwa penggunaan Aspergillus oryzae berpengaruh sangat signifikan terhadap nilai $\mathrm{BK}$ dan SK $(\mathrm{P}<0,05)$, PK dan BETN $(\mathrm{P}<0,01)$ tetapi tidak berpengaruh signifikan terhadap nilai BO dan LK ( $\mathrm{P}>0,05)$. Kesimpulan dari penelitian ini adalah penggunaan Aspergillus oryzae $3 \%$ selama 96 jam untuk memfermentasi kulit ubi kayu merupakan cara terbaik untuk meningkatkan kandungan nutrisi meliputi kadar BK, BO dan BETN serta menurunkan kadar abu, SK dan LK.
\end{abstract}

Kata kunci: Aspergillus oryzae, fermentasi, kualitas kimia, kulit ubi kayu

How to Cite:

Saputri, M. D., \& Chuzaemi, S. (2021). Evaluasi Kualitas Kimia Kulit Ubi Kayu (Manihot Utilissima) yang Difermentasi Menggunakan Inokulan Aspergillus Oryzae. Jurnal Nutrisi Ternak Tropis 4 (1) 24-31
*Corresponding author:

Marlia Dwita Saputri

Email: marlia.dwita24@gmail.com

Mahasiswa Fakultas Peternakan, Universitas Brawijaya Jalan Veteran, Ketawanggede, Kec. Lowokwaru, Kota Malang, Jawa Timur, Indonesia 65145 


\section{ABSTRACT}

The purpose of this study was to determine and evaluate the effect of the level of use of Aspergillus oryzae on the chemical quality of fermented cassava peel (Manihot utilissima). Aspergillus oryzae with different usage levels $(0 \%, 1 \%, 2 \%$ and $3 \%)$ were used for fermentation and incubated for 96 hours. The method used in this study was a laboratory experiment using a completely randomized design (CRD) with 4 treatment methods and 3 replication methods, so that there were 12 units. The variables observed were Dry Matter $(D M)$, Organic Matter (OM), Crude Fiber (CF), Extract Ether (EE), Crude Protein $(C P)$ and Nitrogen Free Extract (NFE). Varian analysis was used to analyze the data and continue with Duncan's Multiple Range Test (DMRT). The results showed that the addition of Aspergillus oryzae had a significant effect on the value of DM and $C F(P<0.05)$, while had very significant effect $(P<0.01)$ on CP and NFE but had no significant effect on OM and EE values $(P>0.05)$. The conclusion of this study is that the use of 3\% Aspergillus oryzae for 96 hours to ferment cassava peels is the best way to increase the nutritional content (DM, OM and NFE) and reduce the levels of ash, CF and EE. The decrease in CP content is due to the reduced nutrient components in the substrate for microbial growth and the lack of addition of other components (such as urea) which causes a decrease in CP during the fermentation process.

Keywords: Aspergillus oryzae, cassava peel, chemical quality, fermentation

\section{PENDAHULUAN}

Salah satu faktor penentu keberhasilan usaha peternakan adalah ketersediaan pakan secara menyeluruh. Faktor penting dalam penyediaan pakan bagi ternak adalah kandungan nutrisi dan ketersediaannya sepanjang tahun (Adli dan Sjofjan, 2020). Pola musim juga umumnya dapat mempengaruhi ketersediaan hijauan yaitu pada musim penghujan ketersediaan melimpah sedangkan musim kemarau terbatas, oleh karena itu perlu dicari sumber pakan lain agar mengurangi ketergantungan pada rumput.

Pemanfaatan limbah pertanian atau industri pangan sebagai pakan alternatif pengganti pakan utama sangat diperlukan sebagai salah satu solusi untuk mengatasi masalah penyediaan pakan utama dan juga sebagai salah satu upaya untuk mengurangi pencemaran lingkungan yang diakibatkannya (Adli dan Sjofjan, 2020). Salah satu limbah pertanian atau industri pangan yang dapat dimanfaatkan untuk pakan ternak adalah kulit ubi kayu. Kulit ubi kayu merupakan salah satu limbah pasca panen yang ketersediaannya melimpah dan dapat dimanfaatkan sebagai bahan pakan.
Berdasarkan data Yuliati, Nasir dan Subagiarta (2019), diketahui luas panen ubi kayu di Indonesia pada tahun 2018 adalah 959.926 ribu hektar dan produksi yang dicapai sebesar 32,8 juta ton dengan produktivitas ubi kayu sebesar 21,85 ton/ha. Menurut Pakpahan, Pujaningsih dan Widiyanto (2018), dari total produksi ubi kayu akan dihasilkan lebih kurang 16\% limbah kulit ubi kayu atau setara dengan 5,25 juta ton.

Nurlaili, Suparwi dan Sutardi (2013) menyatakan bahwa komposisi nutrient kulit ubi kayu yaitu BK $17,45 \%$, protein kasar $8,11 \%$ dan serat kasar $15,20 \%$. Pada dasarnya kulit ubi kayu mengandung nilai nutrisi, namun juga terdapat kandungan anti nutrisi didalamnya berupa asam sianida (HCN) dan dapat membahayakan bagi kesehatan ternak khususnya ruminansia. Salah satu upaya untuk menghilangkan racun asam sianida tersebut adalah dengan metode fermentasi.

Fermentasi merupakan suatu proses perubahan kimia yang berlangsung dengan adanya katalisator biokimia yaitu enzim yang diproduksi oleh mikroba (Adli et al., 2018) Tujuan fermentasi adalah menghasilkan suatu produk (bahan pakan) 
yang mempunyai kandungan nutrisi, tekstur dan biological availibility yang lebih baik, disamping itu juga dapat menurunkan anti nutrisinya (Hersoelistyorini dkk., 2012). Mikroorganisme yang digunakan dalam proses fermentasi kulit ubi kayu ini adalah kapang Aspergillus oryzae. Menurut Jayanti dkk. (2013) Aspergillus oryzae adalah spesies Aspergillus yang memiliki potensi penghasil $\alpha$-amilase. Didukung penelitian Yuliana dan Chuzaemi (2019) menyatakan bahwa nilai tertinggi protein kasar mencapai 27,04\% pada waktu fermentasi 96 jam, hal ini terjadi karena pada waktu fermentasi 96 jam sesuai kurva pertumbuhan Aspergillus oryzae berada pada fase puncak yaitu hari ke-3 dan ke-4 fermentasi, Berdasarkan uraian di atas maka perlu dilakukan penelitian mengenai pengaruh tingkat penggunaan Aspergillus oryzae pada fermentasi kulit ubi kayu yang diinkubasi selama 96 jam fermentasi terhdap kualitas kimia.

\section{MATERI DAN METODE}

\section{Lokasi dan Waktu}

Penelitian dilaksanakan di Laboratorium Nutrisi dan Makanan Ternak, Fakultas Peternakan Universitas Brawijaya, Malang, Jawa Timur.

\section{Materi}

Materi penelitian yang digunakan diantaranya adalah:

1. Kulit ubi kayu (Manihot utilissima), didapatkan dari Pabrik Keripik Singkong Cap Lumba-Lumba yang bertempat di Gg VII B, RT 04/RW 08, Jatirenggo, Talok, Kecamatan Turen, Kabupaten Malang.

2. Jamur Aspergillus oryzae, yang diperoleh dari Laboratorium Biokimia, Fakultas Peternakan Universitas Brawijaya, bentuk tunggal dalam sediaan bubuk.

\section{Metode}

Metode penelitian yang digunakan adalah metode percobaan di laboratorium menggunakan Rencana Acak Lengkap (RAL) dengan 4 perlakuan dan setiap perlakuan diulang $3 \mathrm{kali}$, sehingga terdapat 12 unit sampel percobaan. Perlakuan yang dilakukan adalah sebagai berikut :

$\mathrm{P} 0=$ Kulit ubi kayu + Aspergillus oryzae $0 \%$ difermentasi selama 96 jam

$\mathrm{P} 1=$ Kulit ubi kayu + Aspergillus oryzae $1 \%$ difermentasi selama 96 jam

$\mathrm{P} 2=$ Kulit ubi kayu + Aspergillus oryzae $2 \%$ difermentasi selama 96 jam

P3 = Kulit ubi kayu + Aspergillus oryzae $3 \%$ difermentasi selama 96 jam

\section{Prosedur Fermentasi Kulit Ubi Kayu}

1. Kulit ubi kayu dicuci dan dibersihkan lalu dipotong sekitar ukuran 1-3 cm (Muhiddin dkk, 2001).

2. Diangin-anginkan untuk menurunkan kadar airnya selama 2-3 hari (Akhadiarto, 2009)

3. Ditimbang sebanyak 100 gr.

4. Ditambahkan inokulum Aspergillus oryzae sesuai perlakuan (P0, P1, P2 dan P3) selanjutnya diinkubasi selama 96 jam.

5. Dimasukkan dalam kantong plastik dan difermentasi secara aerob.

6. Dikeringkan di oven $60^{\circ} \mathrm{C}$ lalu digiling dengan ketebalan $1 \mathrm{~mm}$.

7. Dilakukan pengujian analisis proksimat di laboratorium.

\section{Variabel Penelitian}

Variabel yang diamati adalah kandungan nutrien (BK, BO, Abu, SK, LK, PK) dari fermentasi kulit ubi kayu dilakukan dengan menggunakan analisis proksimat menurut (AOAC, 2005).

\section{Analisis Data}

Data yang diperoleh dari penelitian diolah menggunakan program Microsoft Excel. Setelah diperoleh data rata-rata dilanjutkan dengan analisis statistik menggunakan analisis ragam dari Rancangan Acak Lengkap (RAL) (Sudarwati dkk, 2019). Apabila diperoleh hasil yang signifikan maka dilanjutkan dengan Uji Jarak Berganda Duncan (UJBD). 


\section{HASIL DAN PEMBAHASAN}

\section{Kualitas Kimia Fermentasi Kulit Ubi Kayu}

Kulit ubi kayu merupakan bahan pakan dari limbah pasca panen tanaman ubi kayu. Adapun pucuk ubi kayu, batang ubi kayu, bonggol ubi kayu dan onggok tergolong sebagai pakan sumber karbohidrat. Kulit ubi kayu adalah bagian yang mudah dicerna dan cepat terdegradasi di dalam rumen (Antari dan Umiyasih, 2009). Hasil analisis kandungan nutrisi fermentasi kulit ubi kayu ditampilkan pada Tabel 1.

\section{Bahan Kering (BK)}

Tabel 1 menunjukkan bahwa perlakuan pemberian inokulum Aspergillus oryzae dengan level yang berbeda memberikan pengaruh yang berbeda nyata $(\mathrm{P}<0,05)$ terhadap nilai kandungan $\mathrm{BK}$ hasil fermentasi kulit ubi kayu. Berdasarkan hasil Uji Jarak Berganda Duncan menunjukkan bahwa rataan kandungan BK pada perlakuan P0 tidak menunjukkan pengaruh nyata terhadap perlakuan P1 dan P3 namun memberikan pengaruh nyata terhadap perlakuan P2. Perlakuan P2 fermentasi kulit ubi kayu memiliki kandungan BK tertinggi sebesar 21,34\% kemudian mengalami penurunan kembali pada perlakuan P3 yaitu 20,28\%. Menurut penelitian Zega dkk., (2017) bahwa kenaikan BK diduga karena semakin banyaknya mikroorganisme yang tumbuh selama proses fermentasi, maka mengakibatkan hilangnya sejumlah air yang terdapat pada substrat dan mengakibatkan bahan kering menjadi meningkat.

Tabel 1. Rataan Kandungan Nutrisi Fermentasi Kulit Ubi Kayu

\begin{tabular}{ccccccc}
\hline \multirow{2}{*}{ Perlakuan } & \multicolumn{6}{c}{ Kandungan Nutrien (\%) } \\
\cline { 2 - 7 } & BK & BO $^{*}$ & SK $^{*}$ & LK $^{*}$ & PK $^{*}$ & BETN $^{*}$ \\
\hline P0 & $19,70 \pm 1,17^{\mathrm{a}}$ & $93,11 \pm 0,31$ & $25,65 \pm 0,16^{\mathrm{b}}$ & $2,17 \pm 0,62$ & $7,15 \pm 0,32^{\mathrm{b}}$ & $58,13 \pm 1,12^{\mathrm{a}}$ \\
P1 & $19,59 \pm 0,33^{\mathrm{a}}$ & $93,06 \pm 0,23$ & $23,78 \pm 2,11^{\mathrm{ab}}$ & $2,40 \pm 0,32$ & $5,47 \pm 0,84^{\mathrm{ab}}$ & $61,41 \pm 2,51^{\mathrm{ab}}$ \\
P2 & $21,34 \pm 0,57^{\mathrm{b}}$ & $93,08 \pm 0,19$ & $21,63 \pm 0,45^{\mathrm{a}}$ & $2,54 \pm 0,26$ & $4,07 \pm 0,86^{\mathrm{a}}$ & $64,83 \pm 0,46^{\mathrm{bc}}$ \\
P3 & $20,28 \pm 0,12^{\mathrm{ab}}$ & $93,39 \pm 0,08$ & $21,65 \pm 0,81^{\mathrm{a}}$ & $1,81 \pm 0,05$ & $3,95 \pm 0,18^{\mathrm{a}}$ & $65,97 \pm 0,95^{\mathrm{c}}$ \\
\hline
\end{tabular}

Keterangan : - Superskrip yang berbeda pada kolom yang sama menunjukkan perbedaan yang nyata $(\mathrm{P}<0,05)$ terhadap nilai $\mathrm{BK}, \mathrm{BO}, \mathrm{SK}, \mathrm{LK}$.

- Superskrip yang berbeda pada kolom yang samass menunjukkan perbedaan yang sangat nyata $(\mathrm{P}<0,01)$ terhadap nilai PK dan BETN.

*Berdasarkan $100 \%$ BK.

Pada perlakuan P3, BK mengalami penurunan kembali hal ini disebabkan pada saat tingkat penggunaan Aspergillus oryzae $3 \%$ diduga kandungan nutrien yang terdapat dalam substrat mulai berkurang seiring bertambahnya massa sel kapang karena selama proses fermentasi nutrien yang digunakan oleh kapang akan diubah dalam bentuk panas/energi dan $\mathrm{CO}_{2}$ sehingga kadar air mengalami penurunan. Mirwandhono dkk., (2006) menyatakan bahwa karbohidrat yang terkandung dalam substrat tersebut akan dipecah menjadi glukosa kemudian dilanjutkan sampai terbentuk energi dan akan diperoleh hasil samping berupa karbondioksida dan uap air.

\section{Bahan Organik (BO)}

Berdasarkan hasil penelitian, kandungan nutrisi fermentasi kulit ubi kayu menggunakan inokulum Aspergillus oryzae dengan level yang berbeda tiap perlakuan, menunjukkan tidak adanya pengaruh yang nyata $(\mathrm{P}<0,05)$ terhadap kandungan $\mathrm{BO}$ hasil fermentasi kulit ubi kayu. Tinggi rendahnya kandungan organik pada perlakuan juga dimungkinkan oleh aktivitas kapang yang memecah kandungan substrat pada saat proses fermentasi sehingga mempermudah mikroorganisme yang ada untuk mencerna bahan organik. Asriani (2016) mengatakan bahwa bertambahnya massa sel tumbuh pada kapang dan 
terjadinya peningkatan konsentrasi dalam produk karena adanya perombakan bahan organik akibat dari proses fermentasi yang menghasilkan $\mathrm{CO}_{2}$ dan panas.

Menurut Suningsih dkk., (2019) bahwa bahan organik substrat terdiri dari karbohidrat, lemak dan protein. Kapang dalam proses fermentasi merombak ketiga unsur tersebut. Hasil perombakan digunakan kapang untuk kelangsungan hidupnya sehingga jumlah ketiga unsur tersebut mengalami penurunan. Perubahan bahanbahan organik yang didegradasi oleh mikroorganisme menjadi senyawa organik dari substrat menjadi molekul yang lebih sederhana maupun menjadi bentuk lain seperti air dan energi yang digunakan untuk aktivitas mikroorganisme (Antari dan Umiyasih, 2009).

\section{Serat Kasar (SK)}

Berdasarkan hasil penelitian fermentasi kulit ubi kayu setelah fermentasi mengalami penurunan kandungan SK dibandingkan sebelum fermentasi. Bertambahnya tingkat penggunaan Aspergillus oryzae yang digunakan sebagai starter fermentasi kulit ubi kayu berturutturut dalam media fermentasi secara nyata $(\mathrm{P}<0,05)$ mampu menurunkan kadar SK substrat dibanding kontrol (P0). Terjadinya penurunan SK diduga karena faktor tingginya kandungan serat pada substrat sebelum difermentasi, diketahui bahwa kulit ubi kayu tanpa fermentasi memiliki kandungan SK yang cukup tinggi sehingga kondisi ini diduga memacu aktivitas enzim selulase yang dihasilkan oleh kapang Aspergillus oryzae dalam memecah ikatan selulosa.

Menurut Jayanti dkk., (2013) Aspergillus oryzae juga berpotensi menghasilkan enzim amilase dan protease yang berperan dalam memecah amilum dan protein yang terkandung dalam substrat. Penurunan SK juga disebabkan oleh lamanya waktu fermentasi. Semakin lamanya waktu fermentasi maka mikroba akan terus tumbuh, sejalan dengan hasil itu akan semakin banyak pula enzim selulase yang dihasilkan.

\section{Lemak Kasar (LK)}

Pada hasil analisis statistik diketahui bahwa pemberian inokulum Aspergillus oryzae yang bervariasi tidak berpengaruh nyata $(\mathrm{P}>0,05)$ terhadap kandungan LK fermentasi kulit ubi kayu. Berdasarkan hasil penelitian, seiring bertambahnya tingkat penggunaan Aspergillus oryzae maka massa sel kapang juga mengalami peningkatan akibatnya semakin banyak enzim lipase yang dihasilkan oleh sel kapang untuk mendegradasi lemak sehingga kandungan lemak kasar mengalami penurunan. Menurut Kusumaningrum dkk., (2017) kapang setelah menyerang karbohidrat untuk sumber energi, kemudian menyerang lemak dan protein.

Syahrir dan Abdeli (2005) juga mengungkapkan bahwa penurunan kadar LK diduga karena dalam memecah ikatan lignoselulosa mikroba membutuhkan banyak energi sedangkan energi yang terkandung dalam substrat sudah tidak mencukupi (nutrisi semakin berkurang) sehingga mikroba memanfaatkan cadangan energi lain yang berupa lemak untuk memenuhi kebutuhannya.

\section{Protein Kasar (PK)}

Pada Tabel 1 dapat dillihat bahwa penggunaan Aspergillus oryzae yang bervariasi $(0 \%, 1 \%, 2 \%$ dan 3\%) memberikan pengaruh yang sangat nyata $(\mathrm{P}<0,01)$ terhadap nilai kandungan $\mathrm{PK}$ hasil fermentasi kulit ubi kayu. Terjadinya penurunan kandungan PK secara kuantitatif diduga karena kurangnya penambahan zat lain seperti urea pada saat proses fermentasi. Didukung penelitian Yanuartono dkk., (2017) bahwa penambahan dengan urea paling umum digunakan untuk peningkatan nilai nutrisi pada pakan basal dengan kualitas rendah karena penanganannya sederhana. Urea merupakan sumber non protein nitrogen (NPN) yang paling sering digunakan sebagai pakan protein sejati. Hersoelistyorini dkk., (2012) menambahkan bahwa biomassa merupakan wujud massa dari hasil proses biologis mikroorganisme. Mikroorganisme mampu mengonversi bahan menjadi protein namun dalam 
penggunaan analisis proksimat, protein asal mikroba tidak terbaca sebagai nitrogen asal NPN sehingga tidak meningkatkan kandungan PK meskipun kandungan atau pemberian inokulum kapang terbanyak (Sjofjan et al., 2020). Hastuti dkk., (2011) juga mengatakan hal yang sama bahwa penurunan diduga karena jumlah substrat yang sangat diperlukan oleh mikroba yang dapat menunjang pertumbuhannya sudah menipis, sehingga pertumbuhan mikroba terhambat dan sebagian mati. Protein mikroba yang mati mudah didegradasi oleh mikroba lain menjadi amonia yang sebagian akan digunakan lagi oleh mikroba tersebut untuk menyusun tubuhnya dan sebagian lagi menguap.

\section{Bahan Ekstrak Tanpa Nitrogen (BETN)}

Berdasarkan hasil rata-rata kandungan BETN fermentasi kulit ubi kayu pada Tabel 3 diketahui bahwa perlakuan penggunaan Aspergillus oryzae yang bervariasi $(0 \%, 1 \%$, $2 \%$ dan $3 \%$ ) memberikan pengaruh yang sangat nyata $(\mathrm{P}<0,01)$ terhadap nilai kandungan BETN fermentasi kulit ubi kayu. Kenaikan BETN dalam penelitian ini diduga disebabkan karena adanya penurunan kadar abu, LK, SK dan PK pada hasil fermentasi. Dugaan lain terjadinya kenaikan kandungan BETN karena perkembangan Aspergillus oryzae dalam proses fermentasi tidak optimal sehingga kadar karbohidrat yang mudah larut yang digunakan sedikit. Menurut Kusumaningrum dkk., (2012) kandungan BETN semakin meningkat dengan semakin bertambahnya tingkat penggunaan inokulum pada substrat dan banyaknya karbohidrat yang terkandung dalam substrat serta dengan kemampuan Aspergillus niger memecah selulosa. Peningkatan kadar BETN dipengaruhi oleh hilangnya lignin, selulosa dan hemiselulosa dalam proses fermentasi yang mengakibatkan penurunan kandungan serat kasar sehingga dapat meningkatkan kandungan BETN (Zega dkk, 2017).

\section{KESIMPULAN}

Tingkat penggunaan Aspergillus oryzae sebanyak 3\% pada fermentasi kulit ubi kayu yang diinkubasi selama 96 jam merupakan perlakuan yang efisien untuk meningkatkan BK, BO dan nilai kandungan BETN serta mampu menurunkan kandungan abu, LK dan SK namun dalam hal ini kandungan PK mengalami penurunan yang diduga disebabkan oleh berkurangnya nutrien.

\section{DAFTAR PUSTAKA}

Adli, D. N., \& Sjofjan, O. (2020a). Metaanalisis: pengaruh substitusi jagung dengan bahan pakal lokal terhadap kualitas karkas daging broiler. Jurnal Ilmu Peternakan Terapan, 3(2), 4448. https://doi.org/10.25047/jipt.v3i2. 1940

Adli, D. N., \& Sjofjan, O. (2020b). Estimasi dan validasi kandungan energi bekatul sebagai pakan unggas dari komposisi kimia pakan. Jurnal Nutrisi Ternak Tropis, 3(2), 90-96. https://doi.org/ 10.21776/ub.jnt.2020.003.02.6

Adli, D. N., Sjofjan, O., \& Mashudi, M. (2018). A study: nutrient content evaluation of dried poultry waste urea molasses block (dpw-umb) on proximate analysis. Jurnal Ilmu-Ilmu Peternakan, 28(1), 84-89. https://doi. org/10.21776/ub.jiip.2018.028.01.09

Akhadiarto, S. (2016). Pemanfaatan limbah kulit singkong, kulit pisang dan kulit kentang sebagai bahan pakan ternak melalui teknik fermentasi. Jurnal Teknologi Lingkungan, 10(3), 257. https://doi.org/10.29122/jtl.v10i3.1471

Antari, R., \& Umiyasih, U. (2009). Pemanfaatan tanaman ubi kayu dan limbahnya secara optimal sebagai pakan ternak ruminansia. Wartazoa, 19(4), 191-200.

AOAC. (2005). Official Method of Analysis 18th Edition, Association of Official Agricultural Chemist. AOAC International.

Asriani, D. (2016). Kandungan Bahan Organik Dan Protein Kasar Kulit Ubi Kayu Yang Di Fermentasikan Dengan Inokulan Yang Berbeda. Universitas Hasanudin Makasar.

Hastuti, D., Awami, S. N., \& Iskandar, B. 
(2011). Pengaruh perlakuan teknologi amofer (amoniasi fermentasi) pada limbah tongkol jagung sebagai alternatif pakan berkualitas ternak ruminansia. Mediagro, 7(1), 55-65. https://doi.org/10.31942/MD.V7I1.568

Hersoelistyorini, W. Utama, C. S., \& Suryanto, A. (2012). Aplikasi proses ferentasi kulit singkong menggunakan starter asal limbah kubis dan sawi pada pembuatan pakan ternak berpotensi probiotik. Seminar Hasil Penelitian.

Jayanti, D., Wuryanti, \& Taslimah. (2013). Isolasi, karakterisasi, dan amobilisasi $\alpha$-amilase dari aspergillus oryzae FNCC 6004. Chemical Information Journal, 1(1), 76-84.

Kusumaningrum, O. M., Sutrisno, C. I., \& Prasetiyono, B. W. H. E. (2012). Chemical quality of cattle feed and agricultural waste based agricultural by-product fermented with aspergillus niger. Animal Agriculture Journal, 1(2), 109-119.

Mirwandhono, E., Bachari, I., \& Situmorang, D. (2006). Nutrient value test of cassava tuber skin fermented by aspergillus niger. Jurnal Agribisnis Peternakan, 2(3), 91-95.

Muhiddin, N. H. (2001). Peningkatan kandungan protein kulit umbi kayu melalui proses fermentasi. JMS, 6(1), $1-12$.

Nurlaili, F., \& Suparwi. (2013). Fermentasi kulit singkong (Manihot utilissima Pohl) menggunakan aspergillus niger pengaruhnya terhadap kecernaan bahan kering (Kbk) dan kecernaan bahan organik (Kbo) secara in vitro. Jurnal Ilmiah Peternakan, 1(1), 856864.

Pakpahan, P., \& Widi, P. (2019). Evaluasi komposisi nutrien kulit ubi kayu dengan berbagai perlakuan sebagai bahan pakan kambing lokal. Jurnal Pengembangan Penyuluhan Pertanian, 15(28), 57. https://doi.org/ 10.36626/jppp.v15i28.15

Sjofjan, O., Nur Adli, D., Djunaidi, I., \&
Kuncoro, K. (2020). Utilization of biogas liquid waste for starter in the fermentation of rice husk as a potential feed for poultry. ANIMAL PRODUCTION, 22(1), 24-30. https:// doi.org/10.20884/1.jap.2020.22.1.38

Sudarwati, H., Natsir, M. H., \& Nurgiartiningsih, V. M. A. (2019). Statistika dan Rancangan Percobaan Penerapan Dalam Bidang Peternakan. UB Press.

Suningsih, N., Ibrahim, W., Liandris, O., \& Yulianti, R. (2019). Kualitas fisik dan nutrisi jerami padi fermentasi pada berbagai penambahan starter. Jurnal Sains Peternakan Indonesia, 14(2), 191-200. https://doi.org/10.31186/js pi.id.14.2.191-200

Syahrir., \& Abdeli, M. (2005). Analisis kandungan zat-zat makanan kulit buah kakao yang difermentasi dengan Trichoderma sp sebagai pakan ternak ruminansia. Jurnal Agrisains, 6(3), 157-165.

Yanuartono, N. A., Indarjulianto, S., Purnamaningsih, H., \& Rahardjo, S. (2018). Urea: manfaat pada ruminansia. Jurnal Ilmu-Ilmu Peternakan, 28(1), 10-34. https://doi. org/10.21776/ub.jiip.2018.028.01.02

Yuliana, A., \& Chuzaemi, S. (2019). Pengaruh lama fermentasi ampas putak (Corypha gebanga) terhadap kualitas fisik dan kualitas kimia menggunakan aspergillus oryzae. Jurnal Nutrisi Ternak Tropis, 2(1), 19-32. https://doi.org/10.21776/ub. jnt.2019.002.01.3

Yuliati, L., Nasir, M., \& Subagiarta, W. I. (2019). Analisis daya saing komoditas singkong Kabupaten Jember Di Jawa Timur. Seminar Nasional Hasil Penelitian \& Pengabdian Kepada Masyarakat (SNP2M), O(0), 452-457. http://jurnal.poliupg.ac.id/index.php/s np2m/article/view/1985

Zega, A. D., Badarina, I., \& Hidayat, H. (2017). Kualitas gizi fermentasi ransum konsentrat sapi pedaging berbasis lumpur sawit dan beberapa 
bahan pakan lokal dengan bionak dan EM4. Jurnal Sain Peternakan Indonesia, 12(1), 38-46. https:// doi.org/10.31186/jspi.id.12.1.38-46 